\title{
Calcium Dependence of Hypoosmotically Induced Potassium Release in Cultured Astrocytes
}

\author{
Alex S. Bender and Michael D. Norenberg \\ Laboratory of Neuropathology, Veterans Administration Medical Center, Departments of Pathology, Neurosurgery, and \\ Biochemistry and Molecular Biology, University of Miami School of Medicine, Miami, Florida 33101
}

\begin{abstract}
A major mechanism in cell volume regulation after hypoosmotic stress is $K^{+}$release. Our studies show that in astrocytes, $\mathrm{K}^{+}$release during hypoosmotic stress is a $\mathrm{Ca}^{2+}$-dependent process. Agents that increase intracellular $\mathrm{Ca}^{2+}$, such as ionomycin and ouabain, potentiated hypoosmotically stimulated $\mathrm{K}^{+}$release, while compounds that block $\mathrm{Ca}^{2+}$ entry during hypoosmotic stress, such as nimodipine, bepridil, and MK-801, inhibited hypoosmotically stimulated $\mathrm{K}+$ release. Similarly, chelation of intracellular $\mathrm{Ca}^{2+}$ blocked hypoosmotically induced $K^{+}$release. Caffeine and U-73122 also inhibited $\mathrm{K}^{+}$efflux under hypoosmotic conditions, suggesting that intracellular $\mathrm{Ca}^{2+}$ release from $\mathrm{Ca}^{2+}$-induced $\mathrm{Ca}^{2+}$ release stores and inositol trisphosphate-sensitive intracellular $\mathrm{Ca}^{2+}$ stores play a role in the mechanism of $\mathrm{K}^{+}$ release. Blocking the activity of calmodulin, and of CaM kinase, attenuated hypoosmotically induced $\mathrm{K}^{+}$release. Our findings indicate that entry of extracellular $\mathrm{Ca}^{2+}$ and $\mathrm{Ca}^{2+}$ release from intracellular stores play a key role in the activation of $\mathrm{K}^{+}$release under hypoosmotic conditions and thus in cell volume regulation.
\end{abstract}

[Key words: astrocytes, calcium, hypoosmotic stress, potassium, volume regulation]

When exposed to hypoosmotic stress, astrocytes initially swell and then reduce their volume to approximately their original size, a phenomenon referred to as regulatory volume decrease (RVD). The release of ions such as $\mathrm{K}^{+}, \mathrm{Cl}^{-}$, and of various amino acids may play a key role in the mechanism of RVD (Kimelberg et al., 1992). Since RVD is a $\mathrm{Ca}^{2+}$-dependent process in various cell types (McCarthy and O'Neil, 1992), including astrocytes (O'Connor and Kimelberg, 1993), the release of $\mathrm{K}^{+}$ may also be dependent on $\mathrm{Ca}^{2+}$. The influx of $\mathrm{Ca}^{2+}$ during hypoosmotic stress has been observed (Bender et al., 1992b; O'Connor and Kimelberg, 1993), which may he the result of hypoosmotically induced depolarization (Kimelberg and O'Connor, 1988). Voltage-dependent $\mathrm{Ca}^{2+}$ channels are present in astrocytes (Barres, 1991; Howell et al., 1991), and the L-type $\mathrm{Ca}^{2+}$ channel appears to be the one mediating $\mathrm{Ca}^{2+}$ influx

\footnotetext{
Received Aug. 20, 1993; revised Dec. 10, 1993; accepted Dec. 31, 1993.

This work was supported by the Department of Veterans Affairs, GRECC, and USPHS Grants NS-30291 and DK-38153. We thank Dr. Jocelyn H. Bruce for critical reading of this manuscript; Dr. John E. Bleasdale, Department of Cell Biology, ' The Upjohn Company, Kalamazoo, MI, for his generous gift of U-73I22; and Ms. Janina Blicharska for her excellent technical assistance.

Correspondence should be addressed to Alex S. Bender, Ph.D., Department of Pathology (D-33), P.O. Box 016960, University of Miami School of Medicine, Miami, FL 33101

Copyright @ 1994 Society for Neuroscience $0270-6474 / 94 / 144237-07 \$ 05.00 / 0$
}

(O'Connor and Kimelberg, 1993; Bender et al., 1994). $\mathrm{Ca}^{2+}$ influx may also occur as a result of the reversal of the $\mathrm{Na}^{+} / \mathrm{Ca}^{2+}$ exchanger (Kim-Lee et al., 1992; Bender et al., 1993b), which is likewise present in astrocytes (Fatatis and Brenneman, 1990; Blaustein et al., 1991).

The extracellular $\mathrm{Ca}^{2+}$ that enters the cell during hypoosmotic stress may serve as a source for the increase in the intracellular $\mathrm{Ca}^{2+}$ observed in astrocytes (O'Connor and Kimelberg, 1993). Increase in intracellular $\mathrm{Ca}^{2+}$ is important in the mechanism of RVD, since inhibition of hypoosmotically stimulated phosphoinositide hydrolysis inhibits RVD (Bender et al., 1993a). Agents that deplete intracellular $\mathrm{Ca}^{2+}$ also inhibit RVD (Hazama and Okada, 1990; Bender et al., 1991). Intracellular $\mathrm{Ca}^{2+}$ may affect the transduction system that regulates RVD, for example, $\mathrm{Ca}^{2+} / \mathrm{calmodulin}-\mathrm{dependent}$ protein kinase $(\mathrm{CaM} \mathrm{ki}-$ nase) and protein kinase $\mathrm{C}$ (PKC). We have shown that in astrocytes calmodulin antagonists inhibit RVD (Bender et al., 1992a).

The purpose of this study was to investigate the role of $\mathrm{Ca}^{2+}$ in hypoosmotically stimulated $\mathrm{K}^{+}$release. Agents that facilitate $\mathrm{Ca}^{2+}$ entry into the cells, as well as agents that prevent $\mathrm{Ca}^{2+}$ entry and interfere with $\mathrm{Ca}^{2+}$-dependent processes, were tested for their effects on hypoosmotically stimulated $\mathrm{K}+$ release. Our results provide evidence for the $\mathrm{Ca}^{2+}$ dependence of $\mathrm{K}^{+}$release under hypoosmotic conditions in astrocytes and the possible involvement of CaM kinase and $\mathrm{PKC}$ in modulation of $\mathrm{K}^{+}$ release.

Part of this work has been presented in preliminary form (Bender and Norenberg, 1993).

\section{Materials and Methods}

Materials. Bepridil hydrochloride, caffeine, w-conotoxin GVIA, ethylene-bis-(oxyethylenenitrilo)-tetra-acetic acid (EGTA), nickel chloride, nimodipine, ouabain, and phorbol 12-myristate 13-acetate (PMA) were purchased from Sigma Chemical Company (St. Louis, MO). Ionomycin and bis-(o-aminophenoxy)-ethane- $N, N, N^{\prime}, N^{\prime}$-tetra-acetic acid, tetra(acetoxymethyl)-ester (BAPTA/AM) were obtained from Calbiochem Corporation (San Diego, CA). U-73122 (1-[6-[[17 $\beta$-3-methoxyestra1,3,5(10)-trie-17-yl]amino]hexyl]-1H-pyrrole-2,5-dione) was a gift from Dr. John E. Bleasdale from The Upjohn Company (Kalamazoo, MI) $\mathrm{KN}-62$ (1-[N,O-bis(5-isoquinolinesulfonyl)- $N$-methyl-L-tyrosyl]-4phenylpiperazine) and (+)MK-801 (dizocilipine maleate) were purchased from Research Biochemicals Incorporated (Natick, MA). W-7 hydrochloride ( $N$-(6-aminohexyl)-5-chloro-1-naphthalenesulfonamide hydrochloride) was obtained from Seikagaku Kogyo Co., Ltd. (Tokyo, Japan). ${ }^{86}$ Rubidium chloride $(1.72 \mathrm{mCi} / \mathrm{mg})$ and $3-O-\left[\right.$ methyl- $\left.{ }^{3} \mathrm{H}\right]-\mathrm{D}-$ glucose $(87.6 \mathrm{Ci} / \mathrm{mmol})$ were purchased from New England Nuclear Research Products (Boston, MA). All other reagents were of analytical grade.

Agents affecting $\mathrm{Ca}^{2+}$ homeostasis used in this study affect intracellular $\left[\mathrm{Ca}^{2+}\right]_{i}$ in various ways under isoosmotic conditions. Ionomycin, 
being a $\mathrm{Ca}^{2+}$ ionophore, and ouabain (Schlue, 1991) will increase $\left[\mathrm{Ca}^{2+}\right]_{\text {, }}$, whereas BAPTA/AM will chelate intracellular $\mathrm{Ca}^{2+}$ and EGTA will chelate extracellular $\mathrm{Ca}^{2+}$. Caffeine is known to release $\mathrm{Ca}^{2+}$ from intracellular stores and thus it will initially increase $\left[\mathrm{Ca}^{2+}\right]_{i}$. Other agents, such as U-73122, bepridil, nickel, nimodipine, PMA, KN-62, MK-801, W-7, and $\omega$-conotoxin GVIA, are not known to affect $\left[\mathrm{Ca}^{2+}\right]_{i}$ under isoosmotic conditions.

Cell culture. Astrocytic cell cultures were prepared from neonatal (1$2 \mathrm{~d}$ old) rat cerebral cortices and maintained in primary culture, as previously described by Booher and Sensenbrenner (1972) and modified by Ducis et al. (1990). Briefly, the tissue was dissociated and $0.5 \times 10^{6}$ cells were plated in $35 \mathrm{~mm}$ dishes. The cells were grown for at least 3 4 weeks at $37^{\circ} \mathrm{C}$ in a humidified atmosphere containing $5 \% \mathrm{CO}_{2} / 95 \%$ air before being utilized for biochemical studies. After 2 weeks, the cells were maintained with $0.5 \mathrm{~mm}$ dibutyryl cyclic AMP. Based on immunohistochemistry of glial fibrillary acidic protein and glutamine synthetase, at least $95 \%$ of the cell population were astrocytes.

Cellular volume measurements. Cell volume of astrocytes was determined using the method of Kletzien et al. (1975) adopted to astrocytic cultures by Kimelberg and Walz (1988), which measures the transport of 3-O-methyl-[3] $\mathrm{H}]-\mathrm{D}-\mathrm{glucose}$.

$K^{+}$uptake assay. Uptake studies were done as described by Kimelberg and Walz (1988). The assays were performed in bicarbonate-buffered media, $\mathrm{pH} 7.4$, containing $122 \mathrm{mM} \mathrm{NaCl}, 3 \mathrm{mM} \mathrm{KCl}, 25 \mathrm{mM} \mathrm{NaHCO}_{3}$, $1.3 \mathrm{~mm} \mathrm{CaCl}_{2}, 1.2 \mathrm{mM} \mathrm{KH}_{2} \mathrm{PO}_{4}, 0.4 \mathrm{~mm} \mathrm{MgSO}_{4}$, and $10 \mathrm{~mm}$ glucose (total osmolarity, $300 \mathrm{mOsm}$ ). The cells were preincubated in this medium for $20 \mathrm{~min}$ at $37^{\circ} \mathrm{C}$ in $5 \% \mathrm{CO}_{2} / 95 \%$ air to achieve steady state. Uptake experiments were initiated by adding $2 \mu \mathrm{Ci} / \mathrm{ml}{ }^{86} \mathrm{Rb}^{+}$(analog of $\mathrm{K}^{+}$) as $\mathrm{RbCl}$ to the media for various time periods ranging from 0.5 to 60 min. In cultured glia cells ${ }^{86} \mathrm{Rb}^{+}$resembles ${ }^{42} \mathrm{~K}^{+}$, and is extensively employed for the characterization of $\mathrm{K}^{+}$fluxes, as an analog for $\mathrm{K}^{+}$, instead of ${ }^{42} \mathrm{~K}^{+}$, in view of its longer half-life (Kimelberg et al., 1979). The uptake was terminated by washing the cells rapidly seven times with ice-cold 0.32 м sucrose solution. For uptake assays under hypoosmotic conditions, the $\mathrm{NaCl}$ content was reduced to $22 \mathrm{~mm}$ to make the media hypoosmotic (total osmolarity, $110 \mathrm{mOsm}$ ).

$\mathrm{K}^{+}$efflux assay. ${ }^{86}$ Rubidium efflux assays were done as described by Kimelberg et al. (1979) and Holopainen et al. (1989). Cultured cells were incubated in bicarbonate-buffered medium of the same composition as described in the uptake assays, containing $8 \mu \mathrm{Ci} / \mathrm{ml}^{86} \mathrm{Rb}^{+}$for $1 \mathrm{hr}$ at $37^{\circ} \mathrm{C}$. Subsequently, the cells were washed four times with isoosmotic medium. The release experiments were performed by washing cells on the substratum. The efflux of ${ }^{86} \mathrm{Rb}^{+}$was determincd during repeated incubations, and desaturation of the cells was carried out every $2 \mathrm{~min}$ for 30 or $40 \mathrm{~min}$ at $37^{\circ} \mathrm{C}$ in $0.5 \mathrm{ml}$ fresh nonradioactive buffer. At the end of each interval, the media were removed and placed into plastic test tubes and new media were added to the plates. The cells were exposed to hypoosmotic stress $(40 \mathrm{~mm} \mathrm{NaCl} ; 120 \mathrm{mOsm})$ from the 10 th until the 30 th or 40 th $\mathrm{min}$, in the absence or presence of various agents that affect $\mathrm{Ca}^{2+}$. The radioactivities of the collected 2 min fractions and those remaining in the cells at the end of the experiment were measured in a Packard Auto-Gamma $5660 \gamma$ counter. Cell viability under various hypoosmotic conditions was measured by the trypan blue exclusion method and was $99 \%$.

Kinetic analyses of ${ }^{\prime \prime} R b^{+}$efflux. The sum of radioactivity in each wash and the radioactivity left in the cells at the end of the experiment was considered as the total radioactivity present in astrocytes at the beginning of the desaturation procedure. The radioactivity in the cells at each time point was obtained by sequentially subtracting the radioactivity of each wash. The results were expressed as nanomoles of $\mathrm{K}^{+} /$ mg protein or as percentage of ${ }^{86} \mathrm{Rb}^{+}$left in the cells. Desaturation curves of the radioactivity released from the cells as a function of time were analyzed to determine the kinetic components and the release rate constants for ${ }^{86} \mathrm{Rb}^{+}$efflux, using weighted nonlinear least-squares fitting (Marino et al., 1992). The intervals used in the calculations were 0-40 min for isoosmotic conditions and 10-40 min for hypoosmotic conditions. Statistical significance was assessed by ANOVA and Bonferroni post hoc comparisons between experimental and control cultures.

\section{Results}

Effect of hypoosmotic stress on $K^{+}$homeostasis

Figure 1 shows the time course for ${ }^{86} \mathrm{Rb}^{+}$uptake under isoosmotic and hypoosmotic conditions. I he ${ }^{86} \mathrm{~Kb}^{+}$uptake equilibrated at the level of $\sim 850 \mathrm{nmol} / \mathrm{mg}$ protein under isoosmotic

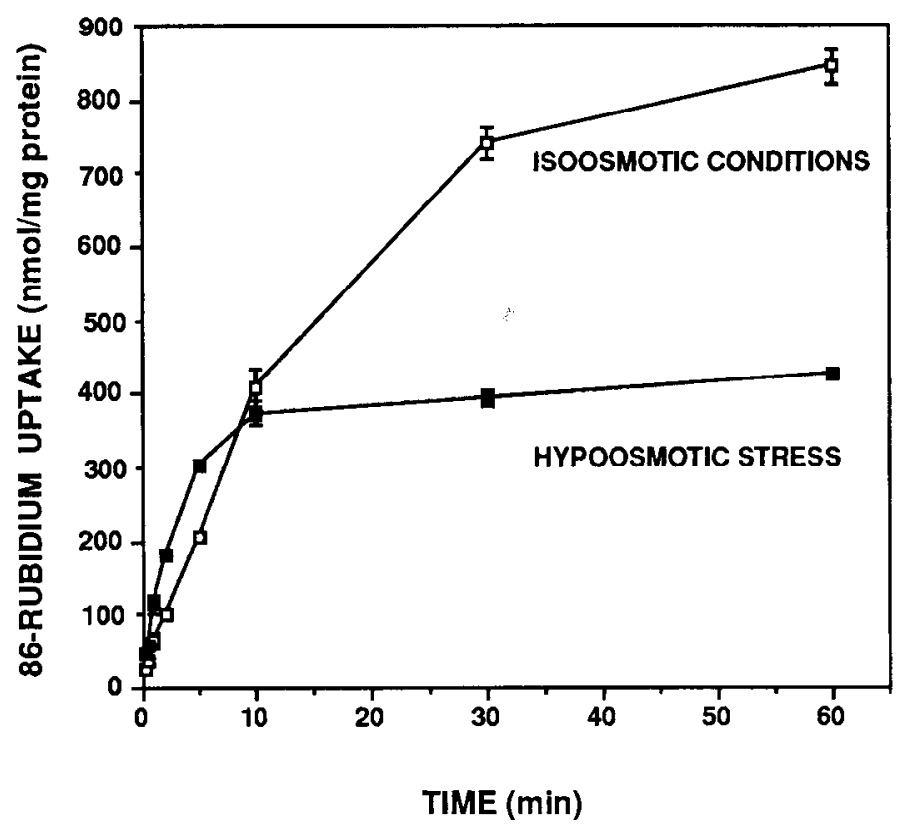

Figure 1. Time course of $\mathrm{K}^{+}$(as ${ }^{86} \mathrm{Rb}^{+}$) uptake under isoosmotic and hypoosmotic ( $110 \mathrm{mOsm})$ conditions. Astrocytcs werc cxposcd to isoosmotic (control; $\square$ ) or hypoosmotic ( $\square$ ) bicarbonate-buffered media containing $2 \mu \mathrm{Ci} / \mathrm{ml}{ }^{86} \mathrm{RbCl}$ for various time periods ranging from 0.25 to $60 \mathrm{~min}$, and ${ }^{86} \mathrm{Rb}^{+}$uptake was determined. Results are expressed as mean \pm SEM of six separate determinations.

conditions and at $\sim 400 \mathrm{nmol} / \mathrm{mg}$ protein under hypoosmotic conditions. Ilowever, the initial rate of ${ }^{86} \mathrm{Rb}^{+}$uptake within the first 10 min was $\sim 50 \%$ higher under hypoosmotic conditions than under isoosmotic conditions.

Figure $2 A$ shows that hypoosmotic stress stimulates ${ }^{86} \mathrm{Rb}^{+}$ efflux. After 2 min of hypoosmotic stress there was a rise in ${ }^{86} \mathrm{Rb}^{+}$release by $\sim 200 \mathrm{nmol} / \mathrm{mg}$ protein, which further increased to $\sim 300 \mathrm{nmol} / \mathrm{mg}$ protein after $10 \mathrm{~min}$. The rate constant for ${ }^{86} \mathrm{Rb}^{+}$release under isoosmotic conditions $(0.0464 \pm$ $0.0008 \mathrm{~min}^{-1} ; n=4$ ) increased by $100 \%$ (to $0.0969 \pm 0.0021$ min $^{-1}$ ) under hypoosmotic conditions. The stimulation of ${ }^{86} \mathrm{Rb}^{+}$ release by hypoosmotic stress is probably responsible for the decrease in equilibrational levels of ${ }^{86} \mathrm{Rb}^{+}$uptake under hypoosmotic conditions.

The time course for stimulation of ${ }^{86} \mathrm{Rb}^{+}$efflux correlates well with the time course of $\mathrm{RVD}$ (see Fig. $2 B$ ), and thus $\mathrm{K}^{+}$release is likely an important factor in volume regulation of astrocytes during osmotic swelling.

\section{Effect of osmolarity on hypoosmotically stimulated ${ }^{86} \mathrm{Rb}$ efflux}

Table 1 shows the dependence of ${ }^{86} \mathrm{Rb}^{+}$efflux on osmolarity, which was decreased from $310 \mathrm{mOsm}$ to $70 \mathrm{mOsm}$, by reducing the $\mathrm{NaCl}$ concentration in the medium from $122 \mathrm{~mm}$ to $0 \mathrm{~mm}$. The rate constants for ${ }^{86} \mathrm{Rb}^{+}$efflux ranged from $0.0435 \pm 0.0003$ $\min ^{-1}(n=4)$ for control $(310 \mathrm{mOsm})$ to $0.1183 \pm 0.0069$ $\min ^{-1}(n=4)$ when osmolarity was reduced to $70 \mathrm{mOsm}$. Statistically significant difference from control (isoosmotic) conditions in ${ }^{86} \mathrm{Rb}^{+}$efflux was first observed when osmolarity was reduced to 230 mOsm ( $p<0.05 ; n=4)$ and became even more pronounced with decreasing osmolarity $(p<0.001)$.

When hypoosmotic media were made isoosmotic with sucrose, $\mathrm{LiCl}$, or choline chloride, there was no significant stim- 


\begin{tabular}{|c|c|c|c|}
\hline $\begin{array}{l}\text { Osmo- } \\
\text { larity } \\
\text { of medium } \\
(\mathrm{mOsm})\end{array}$ & $\begin{array}{l}\text { Concen- } \\
\text { tration } \\
\text { of } \mathrm{NaCl} \\
(\mathrm{mm})\end{array}$ & $\begin{array}{l}\text { Substitution } \\
(\mathrm{mm})\end{array}$ & $\begin{array}{l}\text { Ratc constant for } \\
\mathrm{Rb} \text { efflux (min }{ }^{-1} \text { ) }\end{array}$ \\
\hline 310 & 122 & None & $0.0484 \pm 0.0007$ \\
\hline 110 & 22 & None & $0.0861 \pm 0.0009^{* * *}$ \\
\hline 310 & 22 & Sucrose $(200)$ & $0.0504 \pm 0.0007^{\mathrm{NS}}$ \\
\hline 310 & 22 & $\mathrm{LiCl}(100)$ & $0.0487 \pm 0.0004^{\mathrm{Ns}}$ \\
\hline 310 & 22 & Choline Cl (100) & $0.0512 \pm 0.0006^{\mathrm{Ns}}$ \\
\hline 270 & 102 & & $0.0462 \pm 0.0003^{\mathrm{Ns}}$ \\
\hline 230 & 82 & & $0.0520 \pm 0.0004^{*}$ \\
\hline 190 & 62 & & $0.0540 \perp 0.0003^{*}$ \\
\hline 150 & 42 & & $0.0728 \pm 0.0009^{* *}$ \\
\hline 110 & 22 & & $0.1086 \pm 0.0019^{* * *}$ \\
\hline 70 & 0 & & $0.1183 \pm 0.0069^{* * *}$ \\
\hline
\end{tabular}

Astrocytes were loaded with $8 \mu \mathrm{Ci} / \mathrm{ml} \mathrm{Rb}$ for $1 \mathrm{hr}$ and then were desaturated in isoosmotic (122 $\mathrm{mm} \mathrm{NaCl})$ and hypoosmotic $(22 \mathrm{~mm} \mathrm{NaCl})$ conditions, and in media where $100 \mathrm{~mm}$ of $\mathrm{NaCl}$ was equimolarly substituted with sucrose, $\mathrm{LiCl}$, or choline chloride. The desaturation curves were constructed and rate constants for ${ }^{\prime} \mathrm{Rb}^{\prime}$ efflux under various osmolarities were obtained using weighted nonlinear least-squares fitting (Marino et al., 1992). The results are expressed as means \pm SEM of four separate determinations. The statistical significance between control $(122 \mathrm{~mm} \mathrm{NaCl})$ and various substitutions or osmolarities was assessed by ANOVA and Bonferroni post hoc comparisons. NS, statistically not significant; ${ }^{*}, p<0.05$; ${ }^{* *}, p<0.01 ;{ }^{* * *}, p<0.001$.

ulation of ${ }^{86} \mathrm{Rb}^{+}$release (Table 1 ), suggesting that the reduction in osmolarity rather than the decrease of $\mathrm{NaCl}$ concentration was responsible for stimulation of ${ }^{86} \mathrm{Rb}$ release.

\section{Effect of agents that facilitate or inhibit $\mathrm{Ca}^{2+}$ influx on hypoosmotically stimulated $K^{+}$release}

Figure 3 shows that agents such as ionomycin $(0.5 \mu \mathrm{M})$, a Ca ${ }^{2+}$ ionophore, and ouabain $(500 \mu \mathrm{M})$, an $\mathrm{Na}^{+} / \mathrm{K}^{+}$ATPase inhibitor that increases intracellular levels of $\mathrm{Ca}^{2+}$ by activating the $\mathrm{Na}^{+} /$ $\mathrm{Ca}^{2}+$ exchanger (Blaustein et al., 1991), significantly potentiated hypoosmotically stimulated ${ }^{86} \mathrm{~Kb}^{+}$efflux in astrocytes. Under hypoosmotic conditions, the rate constant for $\mathrm{K}^{+}$efflux was significantly higher in the presence of ionomycin $(0.3464 \pm$ $\left.0.0245 \min ^{1} ; n=4 ; p<0.001\right)$ or ouabain $(0.1868 \pm 0.0071$ $\left.\min ^{-1} ; n=4 ; p<0.05\right)$ than in the absence of either agent $(0.1182 \pm 0.0032 \min$ '; $n=4)$.

Figure 3 also shows that nimodipine, an inhibitor of L-type $\mathrm{Ca}^{2+}$ channels, significantly inhibited hypoosmotically stimulated ${ }^{86} \mathrm{Rb}$ release. The rate constant for ${ }^{86} \mathrm{Rb}^{+}$efflux under hypoosmotic conditions was significantly reduced from 0.1386 $\pm 0.0072 \mathrm{~min}^{1}(n=4)$ to $0.0795 \pm 0.0020 \mathrm{~min}^{1}(n=4 ; p<$ $0.001)$ in the presence of $10 \mu \mathrm{M}$ nimodipinc. Nickel $(100 \mu \mathrm{M})$, a T-type $\mathrm{Ca}^{2+}$ channel blocker, and $\omega$-conotoxin GVIA $(0.5 \mu \mathrm{M})$, an N-type $\mathrm{Ca}^{2+}$ channel blocker, had no effect on hypoosmotically induced $\mathrm{K}^{+}$release. Bepridil $(50 \mu \mathrm{M})$, a nonspecific inhibitor of the $\mathrm{Na}^{+} / \mathrm{Ca}^{2}+$ exchanger, which also inhibits $\mathrm{Ca}^{2+}$ channels (Stys et al., 1991), also reduced hypoosmotically stimulated ${ }^{8}{ }^{6} \mathrm{Rb}^{+}$release to $0.0720 \pm 0.0031 \mathrm{~min}^{-1}(n=4 ; p<$ 0.001 ) (see Fig. 3). Additionally, MK-801 (500 $\mu \mathrm{M})$, which is known to inhibit $\mathrm{Na}^{+} / \mathrm{Ca}^{2}$ exchanger in astrocytes (CornellBell and Kim, 1993), also inhibited hypoosmotically induced $\mathrm{K}^{+}$release. The rate constant for $\mathrm{Rb}^{+}$release under hypoosmotic conditions $\left(0.0914 \pm 0.0004 \mathrm{~min}{ }^{1}\right)$ was reduced in the presence of MK-801 to $0.0765 \pm 0.0006 \mathrm{~min}^{-1}(n=4 ; p<$ $0.001)$.
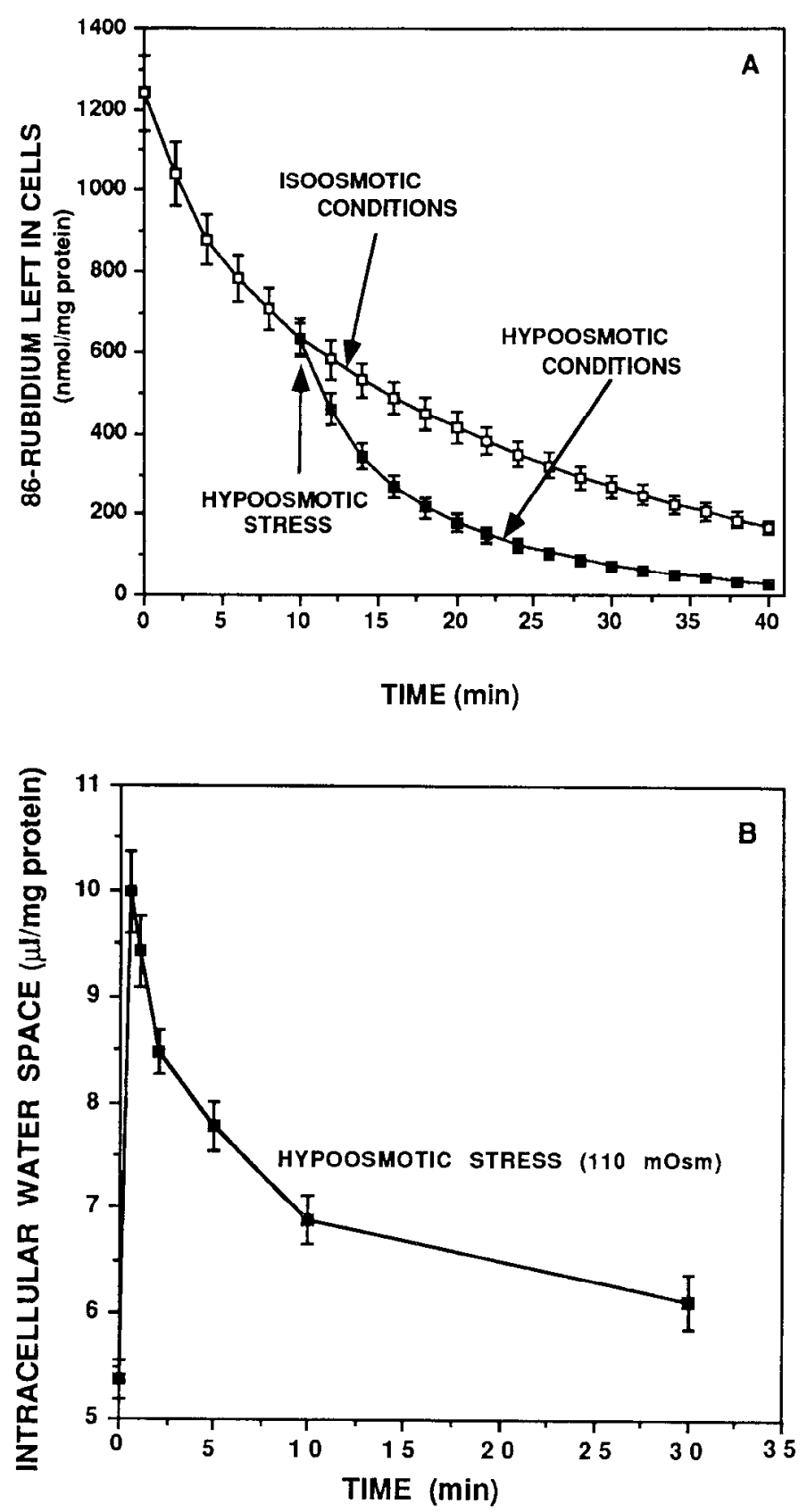

Figure 2. Effect of hypoosmotic stress on $\mathrm{K}^{:}$(as ${ }^{\times 6} \mathrm{Rb}^{-}$) release $(A)$ and on cell volume $(B)$. To determine ${ }^{86} \mathrm{Rb}$ efflux, astrocytes were incubated for $1 \mathrm{hr}$ in the presence of $8 \mu \mathrm{Ci} / \mathrm{ml}$ " $\mathrm{RbCl}$, washed four times, and then desaturated. Cells were exposed to hypoosmotic ( 110 mOsm) stress at the 10 th min and collections continued until the 40 th min. The results represent means \pm SEM of six separate determinations. To examine the cell volume changes under hypoosmotic stress $(B)$, astrocytes were pretreated for $20 \mathrm{~min}$ with isoosmotic bicarbonatebuffered media, and then exposed to hypoosmotic $(110 \mathrm{mOsm})$ media

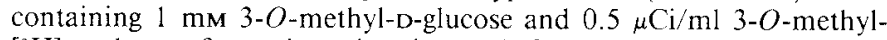
$\left[{ }^{3} \mathrm{H}\right]$-n-glucose for various time intervals from 0 to $30 \mathrm{~min}$. The accumulated radioactivity was converted to $\mu \mathrm{l} / \mathrm{mg}$ protein. Results are expressed as means \pm SEM of six separate determinations.

\section{Effect of extra- and intracellular $\mathrm{Ca}^{2+}$ on hypoosmotically stimulated $K^{+}$release}

Removal of extracellular $\mathrm{Ca}^{2+}$ from the medium enhanced the release of ${ }^{86} \mathrm{Rb}^{+}$stimulated by hypoosmotic conditions; rate constant for ${ }^{86} \mathrm{Rb}^{+}$efflux reached $0.1288 \pm 0.0040 \min { }^{\prime}(n=$ 


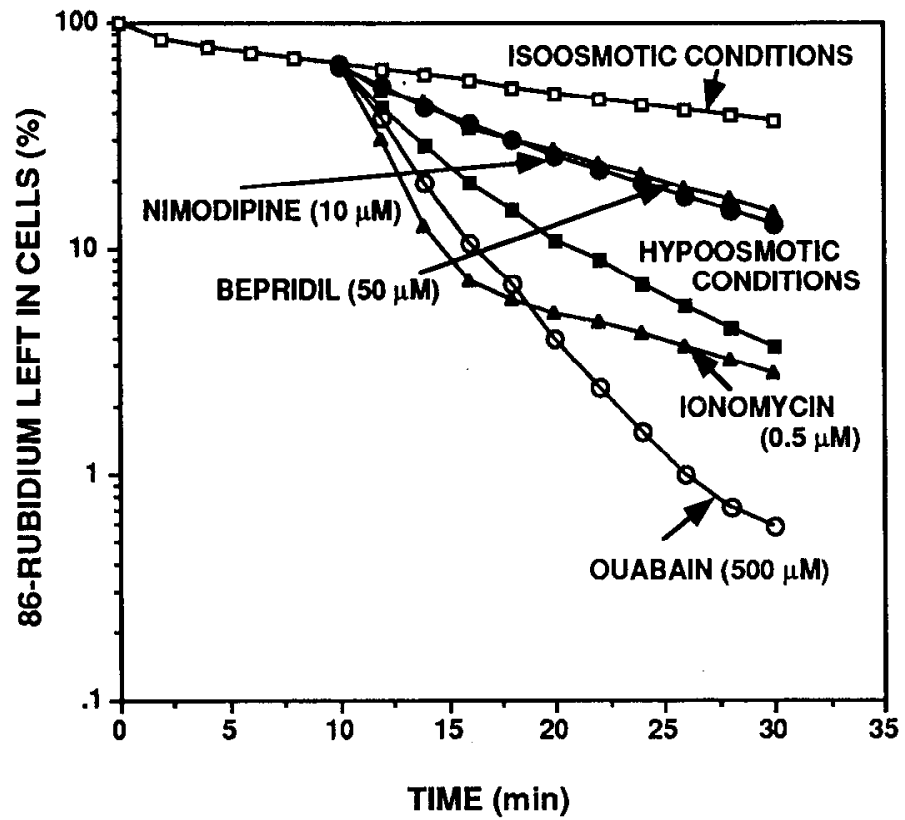

Figure 3. Effect of stimulation of $\mathrm{Ca}^{2++}$ influx and inhibition on hypoosmotically stimulated $\mathrm{K}^{+}$release. Astrocytes were incubated for 1 hr in the presence of $8 \mu \mathrm{Ci} / \mathrm{ml}{ }^{86} \mathrm{RbCl}$, washed four times, and then desaturated. Cells were exposed to hypoosmotic stress in the absence or presence of $0.5 \mu \mathrm{M}$ ionomycin (A) or $500 \mu \mathrm{M}$ ouabain $(O)$ and $10 \mu \mathrm{M}$ nimodipine ( $)$ or $50 \mu \mathrm{M}$ bepridil $(\Delta)$ at the $10 \mathrm{th} \mathrm{min}$, and collections continued until the 30 th min. A single representative study of four identical experiments is shown; SEMs were less than $5 \%$.

4) from $0.0914 \pm 0.0024 \min ^{-1}(n=4 ; p<0.001)$. When 0.1 mM EGTA, in the abscncc of cxtraccllular $\mathrm{Ca}^{2+}$, was added to completely remove extracellular $\mathrm{Ca}^{2+}$, the release of ${ }^{86} \mathrm{Rb}^{+}$under hypoosmotic conditions did not change significantly from that when only extracellular $\mathrm{Ca}^{2+}$ was removed (rate constant was $0.1294 \pm 0.0050 \mathrm{~min}^{-1} ; n=4 ; p<0.001$ ). In the absence of extracellular $\mathrm{Ca}^{2+}$ and presence of EGTA, when intracellular $\mathrm{Ca}^{2+}$ was chelated by BAPTA/AM $(50 \mu \mathrm{M})$, the release of ${ }^{86} \mathrm{Rb}^{+}$ under hypoosmolic conditions did not change (rate constant was $\left.0.1316 \pm 0.0043 \mathrm{~min}^{-1} ; n=4 ; p<0.001\right)$. However, chelation of intracellular $\mathrm{Ca}^{2+}$ with BAPTA/AM $(50 \mu \mathrm{M})$, in the presence of extracellular $\mathrm{Ca}^{2+}$, blocked $\mathrm{K}^{+}$release by $45 \%$ under hypoosmotic conditions within $4 \mathrm{~min}$ of the hypoosmotic exposure $(29,302 \pm 1470$ vs $16,344 \pm 1144 \mathrm{cpm} ; n=4 ; p=$ $0.0004)$.

\section{Role of intracellular $\mathrm{Ca}^{2+}$ stores in hypoosmotically stimulated $K^{+}$release}

Figure 4 shows that caffeine (10 $\mathrm{mm})$ and U-73122 (10 $\mu \mathrm{M})$ inhibited ${ }^{86} \mathrm{Rb}^{+}$efflux under hypoosmotic conditions. Caffeine, which affects $\mathrm{Ca}^{2+}$-induced $\mathrm{Ca}^{2+}$ release (CICR) intracellular $\mathrm{Ca}^{2+}$ stores, reduced the rate constant of ${ }^{86} \mathrm{Rb}^{+}$efflux under hypoosmotic conditions from $0.1219 \pm 0.0039 \mathrm{~min}^{-1}(n=4)$ to $0.0934 \pm 0.0016 \mathrm{~min}^{-1}(n=4 ; p<0.01)$. On the other hand, U-73122, an inhibitor of phospholipase C (Bleásdale et al., 1990) that subsequently prevents phosphoinositide hydrolysis and inositol trisphosphate $\left(\mathrm{IP}_{3}\right)$ formation, also reduced the rate constant of ${ }^{86} \mathrm{Rb}^{+}$release to $0.0825 \pm 0.0028 \mathrm{~min}^{-1}(n=4 ; p<$ $0.001)$. These results suggest that $\mathrm{IP}_{3}$-sensitive $\mathrm{Ca}^{2+}$ stores and CICR $\mathrm{Ca}^{2+}$ stores may be involved in the mechanisms of hypoosmotically stimulated $\mathrm{K}^{+}$release.

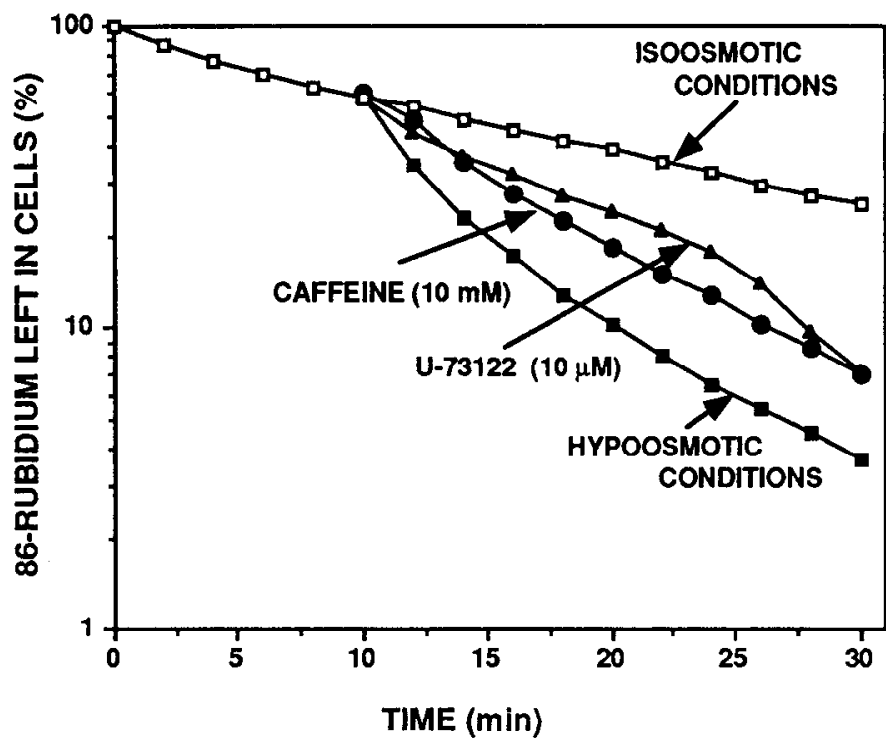

Figure 4. Effect of caffeine and U-73122 on hypoosmotically stimulated $\mathrm{K}^{+}$release. Astrocytes were incubated for $1 \mathrm{hr}$ in the presence of $8 \mu \mathrm{Ci} / \mathrm{ml}{ }^{86} \mathrm{RbCl}$, washed four times, and then desaturated. Cells were exposed to hypoosmotic stress in the presence or absence of caffeine $(10 \mathrm{~mm})$ or $\mathrm{U}-73122(10 \mu \mathrm{M})$ at the $10 \mathrm{th}$ min and collections continued until the 30th min. A single representative study of four identical experiments is shown; SEMs were less than $5 \%$.

Involvement of $\mathrm{Ca}^{2+}$-dependent protein kinases in the modulation of hypoosmotically stimulated $K^{+}$release

Figure $5 A$ shows that $\mathrm{W}-7(50 \mu \mathrm{M})$, a calmodulin antagonist, inhibited hypoosmotically induced ${ }^{86} \mathrm{Rb}^{+}$efflux. The rate constant under hypoosmotic conditions $\left(0.1329 \pm 0.0031 \mathrm{~min}^{-1}\right.$; $n=4)$ was reduced to $0.045 \pm 0.0019 \mathrm{~min}^{-1}(n=4 ; p<0.0001)$ in the presence of $\mathrm{W}-7$. The selective inhibitor of $\mathrm{Ca}^{2+} / \mathrm{cal}-$ modulin-dependent protein kinase II (CaM kinase) KN-62 (20 $\mu \mathbf{M})$ (Tokumitsu et al., 1990; Ishii et al., 1991; Tansey et al., 1992) also reduced rate constant under hypoosmotic conditions to $0.0801 \pm 0.0038 \mathrm{~min}^{-1}(n=4 ; p<0.001)$.

Figure $5 B$ shows that activation of protein kinase $C$ (PKC), after a 30 min treatment with 100 nM PMA, significantly reduced hypoosmotically stimulated ${ }^{86} \mathrm{Rb}^{+}$release. The rate constant of $0.0991 \pm 0.0023 \mathrm{~min}^{-1}(n=4)$ was reduced to 0.0796 $\pm 0.0011 \mathrm{~min}^{-1}(n=4 ; p<0.001)$. When cells were treated with $100 \mathrm{~nm}$ PMA for $13 \mathrm{hr}$ to downregulate $\mathrm{PKC}$, the rate constant for ${ }^{86} \mathrm{Rb}^{+}$release under hypoosmotic conditions was $0.0832 \pm 0.0018 \mathrm{~min}^{-1}(n=4 ; p<0.01)$.

\section{Discussion}

Our results indicate that one of the responses of astrocytes to hypoosmotically induced swelling is an increase in $\mathrm{K}^{+}$permeability. Evidence for a marked increase in $\mathrm{K}^{+}$permeability was obtained from measurements of $\mathrm{K}^{+}$uptake and $\mathrm{K}^{+}$efflux. During osmotically induced cell swelling the initial increase in the rate of $\mathrm{K}^{+}$influx is followed by a loss of intracellular $\mathrm{K}^{+}$, frequently measured as the unidirectional efflux of ${ }^{86} \mathrm{Rb}^{+}$. The initial increase in the rate of $\mathrm{K}^{+}$influx could be possibly due to activation of $\mathrm{Na}^{+} / \mathrm{K}^{+}-\mathrm{ATPase}$ by hypoosmotic stress; such activation has been observed in the skeletal muscle cell (Venosa, 1991). Hypoosmotic stress activates a two- to threefold increase in the rate of ${ }^{86} \mathrm{Rb}^{+}$efflux over the control (isoosmotic) rate, as indicated by the rate constants for $\mathrm{K}^{+}$efflux. This loss in intra- 

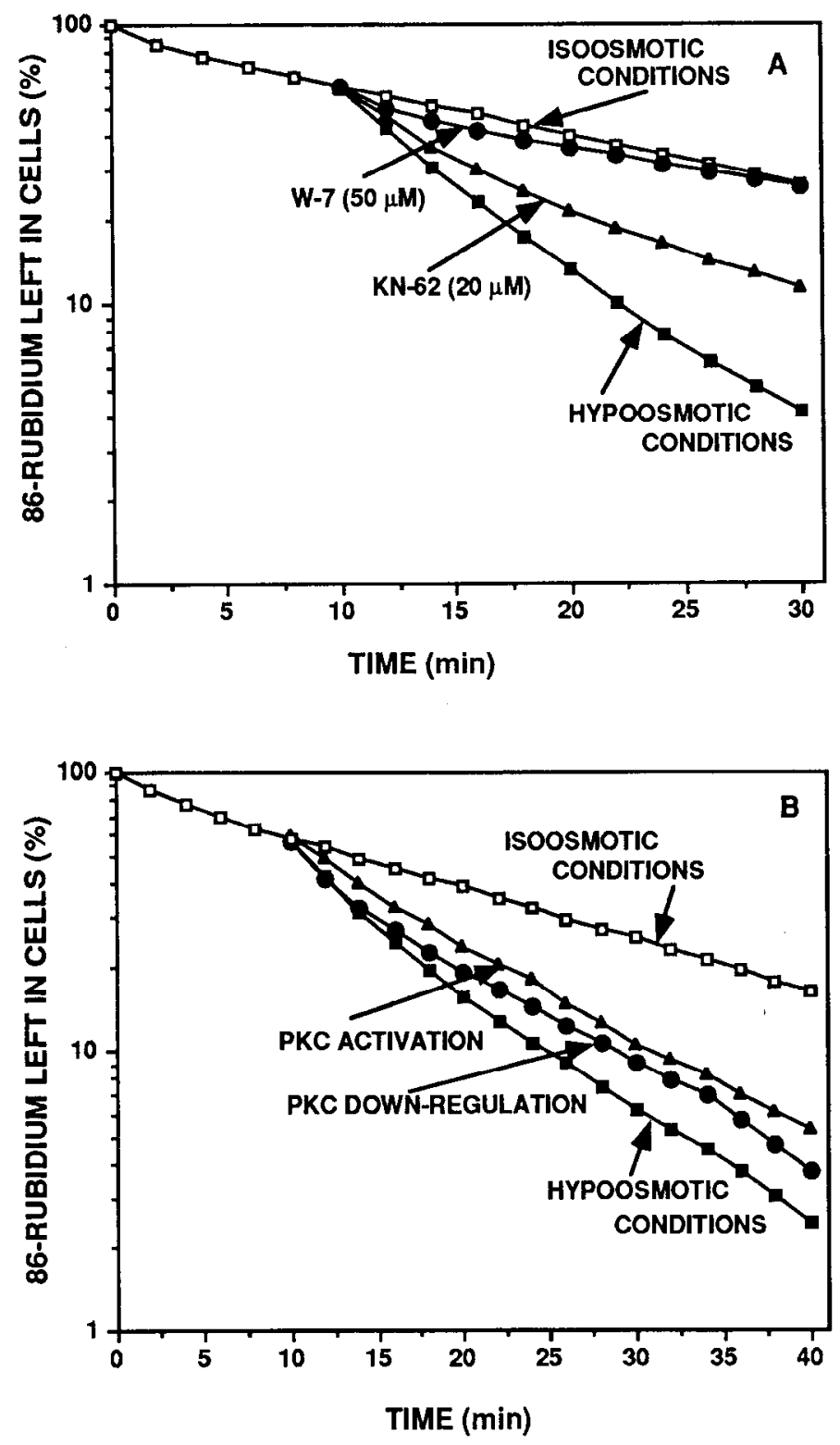

Figure 5. Effect of $\mathrm{W}-7$ and $\mathrm{KN}-62(A)$ and PMA $(B)$ on hypoosmotically stimulated $\mathrm{K}^{+}$release. Astrocytes were incubated for $1 \mathrm{hr}$ in the presence of $8 \mu \mathrm{Ci} / \mathrm{ml}^{86} \mathrm{RbCl}$, washed four times, and then desaturated. Cells were exposed to hypoosmotic stress in the absence or presence of $50 \mu \mathrm{M} \mathrm{W}-7$ or KN-62 $(20 \mu \mathrm{M})$ at the 10 th min, and collections continued until the 30 th min. Cells treated with $100 \mathrm{nM}$ PMA for $30 \mathrm{~min}$ to activate $\mathrm{PKC}$ or for $13 \mathrm{hr}$ to downregulate PKC were also exposed to hypoosmotic stress. A single representative study of four identical experiments is shown; SEMs were less than $5 \%$.

cellular ${ }^{86} \mathrm{Rb}^{+}\left(\mathrm{K}^{+}\right)$roughly parallels the time course of the volume recovery. If coupled to the concomitant efflux of an anion (e.g., $\mathrm{Cl}^{-}$), the loss of $\mathrm{K}^{+}$results in the osmotically obliged movement of water to account for the observed RVD. These findings are consistent with the important role of $\mathrm{K}^{+}$release in volume regulation in other cell types (Haddad and Graf, 1989; Dickman and Goldstein, 1990; Dube et al., 1990; MacLeod et al., 1992; Wehner et al., 1992; Farrugia and Rae, 1993).

$\mathrm{K}^{+}$release was dependent on osmolarity. Stimulation of $\mathrm{K}^{+}$ efflux was observed when osmolarity was reduced to $230 \mathrm{mOsm}$. When media with reduced $\mathrm{NaCl}$ content were made isoosmotic with sucrose, choline chloride, or lithium chloride, there was no stimulation of $\mathrm{K}^{+}$efflux, suggesting that reduction in osmolarity and not $\mathrm{Na}^{+}$omission was responsible for the stimulation of $\mathrm{K}^{+}$efflux under hypoosmotic conditions.

The signals that initiate this $\mathrm{K}^{+}$release could be the influx of extracellular $\mathrm{Ca}^{2+}$ and the release of $\mathrm{Ca}^{2+}$ from intracellular stores. Astrocytes under hypoosmotic stress are able to stimulate $\mathrm{Ca}^{2+}$ uptake and $\mathrm{Ca}^{2+}$ release from intracellular stores (O'Connor and Kimelberg, 1993; Bender et al., 1994). The present study supports the contention that hypoosmotically induced $\mathrm{K}^{+}$ release is dependent on the influx of extracellular $\mathrm{Ca}^{2+}$. Agents that are known to inhibit hypoosmotically stimulated influx of $\mathrm{Ca}^{2+}$, such as nimodipine, bepridil, and MK-801 (Cornell-Bell and Kim, 1993; O'Connor and Kimelberg, 1993; Bender et al., 1994), also inhibited the $\mathrm{K}^{+}$efflux under hypoosmotic conditions. By contrast, agents that stimulate $\mathrm{Ca}^{2+}$ influx, such as ionomycin and ouabain, potentiated hypoosmotically induced $\mathrm{K}^{+}$release.

Intracellular $\mathrm{Ca}^{2+}$ stores could also play an important role in the mechanism of $\mathbf{K}^{+}$release and RVD. We have previously shown that inhibition of phospholipase $C$ and the consequent blockage of hypoosmotically stimulated inositol phosphate hydrolysis by U-73122 resulted in inhibition of RVD (Bender et al., 1994). In this study we show that U-73122 significantly inhibited $\mathrm{K}^{+}$efflux under hypoosmotic conditions, indicating that $\mathrm{Ca}^{2+}$ from $\mathrm{IP}_{3}$-sensitive intracellular $\mathrm{Ca}^{2+}$ stores may play a role in activating $\mathrm{K}^{+}$release during hypoosmotic stress. It was previously shown that CICR intracellular $\mathrm{Ca}^{2+}$ stores are involved in volume regulation in human epithelial cells (Hazama and Okada, 1990). Caffeine, which affects these $\mathrm{Ca}^{2+}$ stores, inhibited RVD in astrocytes (Bender et al., 1991). Hypoosmotically stimulated $\mathrm{K}^{+}$release in astrocytes is also sensitive to caffeine. Therefore, CICR also may play a role in the mechanism of $\mathrm{K}^{+}$efflux under hypoosmotic stress. When intracellular $\mathrm{Ca}^{2+}$ is chelated with BAPTA/AM, there was also a $45 \%$ inhibition of hypoosmotically stimulated $\mathrm{K}^{+}$release, further supporting the contention that intracellular $\mathrm{Ca}^{2+}$ is important in the mechanism of $\mathrm{K}^{+}$efflux under hypoosmotic conditions.

Our results indicate that influx of extracellular $\mathrm{Ca}^{2+}$ and $\mathrm{Ca}^{2+}$ released from $\mathrm{IP}_{3}$-sensitive and $\mathrm{CICR} \mathrm{Ca}^{2+}$ stores may play a role in the mechanism of $\mathrm{K}^{+}$release under hypoosmotic stress. However, when extracellular $\mathrm{Ca}^{2+}$ is omitted from the media there is an increase in the hypoosmotically stimulated $\mathrm{K}^{+}$release. Furthermore, adding EGTA (to chelate the remaining extracellular $\mathrm{Ca}^{2+}$ ) or BAPTA/AM (to chelate intracellular $\mathrm{Ca}^{2+}$ ) did not significantly affect hypoosmotically stimulated $\mathrm{K}^{+}$release in the absence of extracellular $\mathrm{Ca}^{2+}$. In astrocytes from rat cerebellum, omission of $\mathrm{Ca}^{2+}$ in the presence of EGTA caused stimulation of $\mathrm{K}^{+}$release under isoosmotic conditions, but not under hypoosmotic conditions (Sanchez-Olea et al., 1993). Dependence on external $\mathrm{Ca}^{2}+$ for $\mathrm{K}^{+}$influx and efflux was described in cultured glial cells from chick embryonic brain where a decrease of extracellular $\mathrm{Ca}^{2+}$ below $0.1 \mathrm{~mm}$ resulted in a decrease of intracellular $\mathrm{K}^{+}$(I at7kovits et al., 1982). Extracellular $\mathrm{Ca}^{2+}$ is required for membrane stability, and thus removal of extracellular $\mathrm{Ca}^{2+}$ perhaps makes membranes more permeable to $\mathrm{K}^{+}$.

Hypoosmotically stimulated $\mathrm{K}^{+}$efflux is $\mathrm{Ca}^{2+}$ dependent and may be mediated through $\mathrm{Ca}^{2+}$-activated $\mathrm{K}^{+}$channels. Such channels have been described in astrocytes (Quandt and MacVicar, 1989; Barres et al., 1990; Tse et al., 1992). $\mathrm{Ca}^{2+}$. activated $\mathrm{K}^{+}$channels are activated by increases in intracellular $\mathrm{Ca}^{2+}$ levels and by membrane depolarizations. In primary cul- 
tured proximal tubule cells hypoosmotic stress activated maxi $\mathrm{K}^{+}$channels, which required external $\mathrm{Ca}^{2+}$, although some residual single-channel activity was measured in the absence of extracellular $\mathrm{Ca}^{2+}$ (Dube et al., 1990). Such channels could also be involved in mediating $\mathrm{K}^{+}$release under hypoosmotic conditions in astrocytes.

The hypoosmotically stimulated $\mathrm{K}^{+}$release is modulated by $\mathrm{Ca}^{2+}$-dependent protein kinases such as CaM kinase and PKC. An inhibitor of CaM kinase, KN-62 (Tokumitsu et al., 1990; Ishii et al., 1991; Tansey et al., 1992), partially inhibited the $\mathrm{K}^{+}$release under hypoosmotic conditions, whereas $\mathrm{W}-7$, a calmodulin antagonist, almost completely inhibited $\mathrm{K}^{+}$release, suggesting that perhaps calmodulin-dependent enzymes besides CaM kinase (e.g., $\mathrm{Ca}^{2+} /$ calmodulin-dependent phosphatase, calcineurin) may modulate $\mathrm{K}^{+}$release. Previously, we have shown that RVD is blocked by W-7 (Bender et al., 1992a). PKC may also be implicated in the modulation of $\mathrm{K}^{+}$release under hypoosmotic conditions, since acute and prolonged treatment with PMA, to activate and downregulate PKC, respectively, also inhibited $\mathrm{K}^{+}$efflux, a finding that is consistent with the inhibition of RVD by PMA (Bender et al., 1992a). Also, PMA treatment inhibits $\mathrm{K}^{+}$uptake in mouse cultured astrocytes (Bender et al., 1988).

In summary, our results suggest an important role of $\mathrm{Ca}^{2+}$ in $\mathrm{K}^{+}$release following hypoosmotic challenge and thus in cell volume regulation. Extracellular $\mathrm{Ca}^{2+}$ influx and intracellular $\mathrm{Ca}^{2+}$ release during hypoosmotic stress appears to initiate $\mathrm{K}^{+}$ release, possibly by activating $\mathrm{Ca}^{2+}$-dependent $\mathrm{K}^{+}$channels or perhaps by affecting $\mathrm{Ca}^{2+}$-dependent kinases and phosphatases.

\section{References}

Barres BA (1991) New roles for glia. J Neurosci 11:3685-3694

Barres BA, Chun LLY, Corey DP (1990) Ion channels in vertebrate glia. Annu Rev Neurosci 13:441-474.

Bender AS, Norenberg MD (1993) $\mathrm{Ca}^{2+}$ dependence of hypoosmotically-stimulated $\mathrm{K}^{+}$efflux in astrocytes. Trans Am Soc Neurochem 24: 122 .

Bender AS, Hert $\angle$ L, Woodbury DM, White HS (1988) Potent modulation of potassium $\left(\mathrm{K}^{+}\right)$uptake into astrocytes by protein kinase C (PKC). Soc Neurosci Abstr 14:1057.

Bender AS, Blicharska J, Neary JT, Norenberg MD (1991) Intracellular $\mathrm{Ca}^{2+}$ mobilization and astrocytic volume regulation. Trans Am Soc Neurochem 22:133.

Bender AS, Neary JT, Blicharska J, Norenberg LOB, Norenberg MD (1992a) Role of calmodulin and protein kinase in astrocytic cell volume regulation. J Neurochem 58:1874-1882.

Bender AS, Neary JT, Norenberg MD (1992b) Involvement of second messengers and protein phosphorylation in astrocyte swelling. Can J Physiol Pharmacol 70:S362-S366.

Bender AS, Neary JT, Norenberg MD (1993) Role of phosphoinositide hydrolysis in astrocyte volume regulation. J Neurochem 61:15061514.

Bender AS, Mantelle LL, Norenberg MD (1994) Stimulation of calcium uptake in cultured astrocytes by hypoosmotic stress-effect of cyclic AMP. Brain Res, in press.

Blaustein MP, Goldman WF, Fontana G, Krueger BK, Santiago EM, Steele TD, Weiss DN, Yarowsky PJ (1991) Physiological roles of the sodium-calcium exchanger in nerve and muscle. Ann NY Acad Sci 639:254-274.

Bleasdale JE, Thakur NR, Gremban RS, Bundy GI, Fitzpatrick FA Smith RJ, Bunting S (1990) Selective inhibition of receptor-coupled phospholipase $\mathrm{C}$-dependent processes in human platelets and polymorphonuclear neutrophils. J Pharmacol Exp Ther 255:756-768.

Booher J, Sensenbrenner M (1972) Growth and cultivation of dissociated neurons and glial cells from embryonic chick, rat and human brain in flask cultures. Neurobiology 2:97-105.

Cornell-Bell AH, Kim W (1993) The $\mathrm{Na}^{+} / \mathrm{Ca}^{2+}$ exchanger and astrocyte $\mathrm{Ca}^{2+}$ waves. J Neurochem 61:\$248A.
Dickman KG, Goldstein L (1990) Cell volume regulation by skate erythrocytes: role of potassium. Am J Physiol 258:R 1217-R 1223.

Dube L, Parent L, Sauve R (1990) Hypotonic shock activates a maxi $\mathrm{K}^{+}$channel in primary cultured proximal tubule cells. Am J Physiol 259:F348-F356.

Ducis I, Norenberg LOB, Norenberg MD (1990) The benzodiazepine receptor in cultured astrocytes from genetically epilepsy-prone rats. Brain Res 531:318-321.

Farrugia G, Rae J (1993) Effect of volume changes on a potassium current in rabbit corneal epithelial cells. Am J Physiol 264:C1238C1245.

Fatatis A, Brenneman DE (1990) Characterization of the $\mathrm{Na}^{+}-\mathrm{Ca}^{2+}$ exchange in astrocytes. In: Differentiation and functions of glia cells (Levi G, ed), pp 291-292. New York: Wiley-Liss.

Haddad P, Graf J (1989) Volume-regulatory $\mathrm{K}^{+}$fluxes in the isolated perfused rat liver: characterization by ion transport inhibitors. Am J Physiol 257:G357-G363.

Hazama A, Okada Y (1990) Involvement of $\mathrm{Ca}^{2+}$-induced $\mathrm{Ca}^{2+}$ release in the volume regulation of human epithelial cells exposed to a hypotonic medium. Biochem Biophys Res Commun 167:287-293.

Holopainen I, Louve M, Enkvist MOK, Akerman KEO (1989) ${ }^{86}$ Rubidium release from cultured primary astrocytes: effects of excitatory and inhibitory amino-acids. Neuroscience 30:223-229.

Howell MC, Litzinger MJ, Skeen GA, White HS (1991) Expression of an $\left.{ }^{125} I\right] \omega$-conotoxin-sensitive binding site in mouse cortical astrocytes. Soc Neurosci Abstr 17:1161.

Ishii A, Kiuchi K, Kobayashi R, Sumi M, Hidaka H, Nagatsu T (1991) A selective $\mathrm{Ca}^{2+} /$ calmodulin-dependent protein kinase II inhibitor, $\mathrm{KN}-62$, inhibits the enhanced phosphorylation and the activation of tyrosine hydroxylase by $56 \mathrm{~mm} \mathrm{~K}^{+}$in rat pheochromocytoma $\mathrm{PC} 12 \mathrm{~h}$ cells. Biochem Biophys Res Commun 176:1051-1056.

Kimelberg HK, O'Connor ER (1988) Swelling-induced depolarization of astrocyte membrane potentials. Glia 1:219-224.

Kimelberg HK, Walz W (1988) Ion transport and volume measurements in cell cultures. In: Neuronal microenvironment. Neuromethods, Vol 9 (Boulton AA, Baker GB, Walz W, eds), pp 441-492. Clifton, NJ: Humana.

Kimelberg HK, Bowman C, Biddlecome S, Bourke RS (1979) Cation transport and membrane potential properties of primary astroglial cultures from neonatal rat brains. Brain Res 177:533-550.

Kimelberg HK, Sankar P, O'Connor ER, Jalonen T, Goderie SK (1992) Functional consequences of astrocytic swelling. In: Progress in brain research, Vol 94, Neuronal-astrocytic interactions. Implications for normal and pathological $\mathrm{CNS}$ functions ( $\mathrm{Yu} \mathrm{ACH}$, Hertz $\mathrm{L}$, Norenberg MD, Sykova E, Waxman SG, eds), pp 57-68. Amsterdam: Elsevier.

Kim-Lee MH, Stokes BT, Yates AJ (1992) Reperfusion paradox: a novel mode of glia cell injury. Glia 5:56-64.

Latzkovits L, Rimanoczy A, Juhasz A, Torday C, Sensenbrenner M (1982) Control of cation transport in cultured glial cells by external $\mathrm{Ca}^{2+}$ : a possible signal in glial-neuronal interaction. Dev Ncurosci 5:92-100.

MacLeod RJ, Lembessis P, Hamilton JR (1992) Effect of osmotic swelling on $\mathrm{K}^{+}$conductance in jejunal crypt epithelial cells. Am J Physiol 262:G1021-G1026.

Marino AT, DiStefano JJ III, Landaw EM (1992) DIMSUM: an expert system for multiexponential model discrimination. Am J Physiol 262: E546-E556.

McCarthy NA, O'Neil RG (1992) Calcium signaling in cell volume regulation. Physiol Rev 72:1037-1061.

O'Connor ER, Kimelberg HK (1993) Role of calcium in astrocyte volume regulation and in the relcase of ions and amino-acids. J Neurosci 13:2638-2650.

Quandt FN, MacVicar BA (1986) Calcium activated potassium channels in cultured astrocytes. Neuroscience 19:29-41.

Sanchez-Olea R, Moran J, Martinez A, Pasantes-Morales H (1993) Volume-activated $\mathrm{Rb}^{+}$transport in astrocytes in culture. Am J Physiol 264:C836-C842.

Schlue WR (1991) Effects of ouabain on intracellular ion activities of sensory neurons of the leech central nervous system. J Neurophysiol $65: 736-746$

Stys PK, Waxman SG, Ranson BR (1991) $\mathrm{Na}^{+}-\mathrm{Ca}^{2+}$ exchanger mediates $\mathrm{Ca}^{2+}$ influx during anoxia in mammalian central nervous system white matter. Ann Neurol 30:375-380.

Tansey MG, Word RA, Hidaka H, Singer HA, Schworer CM, Kamm 
KE, Stull JT (1992) Phosphorylation of myosin light chain kinase by the multifunctional calmodulin-dependent protein kinase II in smooth muscle cells. J Biol Chem 267:12511-12516.

Tokumitsu H, Chijiwa T, Hagiwara M, Mizutani A, Terasawa M, Hidaka $\mathrm{H}$ (1990) $\mathrm{KN}-62,1$-[N,O-bis(5-isoquinolinesulfonyl)- $N$-methyl-L-tyrosyl]-4-phenylpiperazine, a specific inhibitor of $\mathrm{Ca}^{2+} /$ calmodulin-dependent protein kinase II. J Biol Chem 265:431 5-4320.

Tse FW, Fraser DD, Duffy S, MacVicar BA (1992) Voltage-activated
$\mathrm{K}^{+}$currents in acutely isolated hippocampal astrocytes. $\mathbf{J}$ Neurosci 12:1781-1788.

Venosa RA (1991) Hypo-osmotic stimulation of active $\mathrm{Na}^{+}$transport in frog muscle: apparent upregulation of $\mathrm{Na}^{+}$pumps. $\mathrm{J}$ Membr Biol 120:97-104.

Wehner F, Beetz G, Rosin-Steiner S (1992) Osmolarity reduction transiently increases $\mathrm{K}^{+}$conductance of confluent rat hepatocytes in primary culture. Am J Physiol 263:G913-G919. 